\title{
THE IMPLEMENTATION OF SCIENTIFIC LEARNING APPROACH AT 10th GRADE ENGLISH CLASES OF SENIOR HIGH SCHOOL 4 KOTA BENGKULU
}

\author{
Hikma Wipaqi \\ Azwandi \\ Arono \\ University of Bengkulu \\ Bengkulu, Indonesia 38225 \\ wipaqi@yahoo.com
}

\begin{abstract}
The purpose of this research is to determine the application of the scientific approach in teaching of English for $10^{\text {th }}$ grade at Senior High School 4 Bengkulu City. This research used the descriptive method. The subject of this research was the English teacher at Senior High School 4 Kota Bengkulu. The number of participants in this research were 3 English teachers who tough in $10^{\text {th }}$ grade. This study used observation checklist as an instrument. Observation checklist consisted of three main components. The first component consisted of five phases of scientific approach. They were observing, asking, exploring, associating and communicating. The second component was learning materials that supported the implementation of scientific learning approach and the third component was an assessment in scientific learning approach. The results of this study indicated that the implementation of scientific learning approach included the all five phases reached an average of 3.13 ( in 'good 'category), observing phase reached an average 2.80 ( in 'fair" category), asking phase reached an average of 3.15 ( in 'good; category), exploring phase reached an average of 3.18 ( in' good 'category), phase associating reached an average of 3.47 (in 'very good' category) and communicating phase reached an average of 3.06 (in' good 'category). The second component of development of the material reached an average of 3.72 ( in' very good' categories) and the third component was an assessment reached 3.67 (in 'very good' category).
\end{abstract}

Keywords: curriculum, implementation, scientific learning approach

\begin{abstract}
ABSTRAK
Tujuan penelitian ini untuk mengetahui penerapan pendekatan saintifik pada pembelajaran Bahasa Inggris pada kelas 10 SMAN Negeri 4 Kota Bengkulu. Penelitian ini menggunakan metode deskriptif. Subjek dari penelitian ini guru Bahasa Inggris di SMA Negeri 4 Kota Bengkulu. Jumlah partisipan dalam penelitian ini 3 orang guru Bahasa Inggris yang mengajar pada kelas 10 . Dalam penelitian ini peneliti menggunakan ceklis observasi sebagai instrument. Ceklis observasi terdiri dari 3 komponen utama. Komponen pertama terdiri dari lima fase dari pendekatan scientific yaitu fase mengamati, menanya, mengeksplorasi, mengasosiasi dan mengkomunikasikan. Komponen ke dua megenai materi pembelajaran yang mendukung pelaksanaan pendekatan saintifik dan komponen ke tiga adalah penilian yang dilakukan dalam pendekatan saintifik. Dari hasil penelitian ini menunjukkan bahwa implementasi penekatan saintifik yang mencakup ke lima fase tersebut mencapai rata-rata 3.13 dengan katagori baik yaitu pada pase mengamati mencapai rata rata 2.80 , fase menanya mencapai rata-rata 3.15 dengan katagori baik, fase eksplorasi mencapai rata-rata 3.18 dengan katagori baik, fase mengasosiasi mencapai rata-rata 3.47 dengan katagori sangat baik dan terakhir fase mengkomunikasikan mencapai rata-rata 3.06 dengan katagori baik. Komponen ke dua mengenai pengembangan materi mencapai rata-rata 3.72 dengan katagori sangat baik dan katagori ke tiga megenai penilaian meancapai 3.67 dengan katagori sangat baik.
\end{abstract}

Kata Kunci : Kurikulum, Implementasi, Pendekatan Pembelajaran saintifik 


\section{INTRODUCTION}

Educational Curriculum in Indonesia always run into change and develops. The curriculum is always dynamist. It is followed by logic concision of changing in system political, socio cultural, economy and the development of technology. All of these national curriculums are designed base on the same foundation, Pancasila and UUD 1945. But the differentiation is based on the main purpose, approach and their implementation.

Scientific Approach has been known in KTSP Curriculum in 2007/2008 where particularly this learning focuses on learners. The changes in 2013 curriculum focus on four standardization. They are graduation competency, process, content and assessment. The concept of this new curriculum was taken from the old curriculum that basically focus on learning process just fulfils the target of student's knowledge. In 2013 curriculum, the learner seek the knowledge not receive it. This approach has the same purpose with the approach of skill process. The balances of between hard skill and soft skill are specificity from this curriculum. In fact, the problem of approach is not the curriculum problem but the implementation problem where the implementation of it isn't run well. It can be the scientific approach in 2013 curriculum will face the same problem if the teacher doesn't understand how to implement this approach in class. The process of scientific approach have some learning phases consists of observing, questioning, collecting information/experimenting, associating and communicating, the materials are developed by the teacher to support the implementation scientific approach and the teacher do assessment the learning process and product in implemented the scientific approach in class,

Teachers had many inspirations about how to implement the new approach to the learning and teaching process. The English teacher admitted after following some inquiry activities. She falls back to the lecture based on the student's confusion that is caused that commonly the teacher's teaching based on the exiting materials where the students accustom to just receive the knowledge without having some effort to get the knowledge and solve the learning problem by themselves. She got difficulties to teach in limited time with in it. To change this paradigm the appropriate way that teacher do was how to make the teaching and learning process have meaningful. It means that teacher can teach such away to make the students take a part in this process. Agnes Tuti Rumiati, as a Particular Staff Minister of Education and Culture Development Supervision and Control fields (UKMP3) that there are many things that teacher still doesn't understand relate to 2013 curriculum. The first is compliable in assessment. Teacher still confused how to assess in this curriculum; the second one was how to implement the scientific approach in teaching learning process in class, and the last one is how to make the students active. It is caused by the teacher still didn't understand how to motivate the students in the scientific process in learning. Teacher had noticed that the confusion of students in facing the new style in teaching and learning process, the researcher would do the research in order to know the implementation of scientific approach in English class.. The function of the teacher supported the students to get something new by discovering is a process of scientific approach itself.

Scientific Approach in teaching and learning process is a new phenomenon where the teacher and students still confused about that. It is caused that the teacher lack $o$ knowledge and experience to develop this way and the student's fell that is something new for them. In fact, scientific learning approach is 
implemented very limited in English class. In this case this research will describe how the Implementation of Scientific Learning Approach in English Classes is at $10^{\text {th }}$ grade of Senior High School 4 Kota Bengkulu Academic Year 2016-2017

This research was limited to the Implementation of Scientific Learning Approach in English classes. In this study the Scientific Learning Approach refers to an approach which steps are observing, questioning, associating, experimenting and networking/communicating.; the materials could be developed in scientific learning approach, and conducting the assessments in scientific learning approach. The observation was being

\section{RESEARCH METODOLOGY}

This research employed the Descriptive Research Design. The descriptive method describes or explains about the present condition and situation (Arikunto, 1998). This research describe $\mathrm{s}$ the learning activities in English classes that implement the 2013 Curriculum that aims getting clear description of the implementation of scientific learning approach at $10^{\text {th }}$ grade of Senior High School 4 Kota Bengkulu

\section{RESULT AND DISCUSSION}

It describes the analysis of the implementation of Scientific Learning Approach based on the 2013 Curriculum in English classes at Senior High School Number 4 Kota Bengkulu, also discussed in the findings of the research. According to the regulation of government number 81 A 2013, there are five steps in Scientific Learning Approach that should be done by the teacher. They are observing, questioning, exploring, associating, and
The subject of the research was the teacher in Senior High School 4 Bengkulu City in 2016-2017 Academic Year. This school has the implemented the 2013 Curriculum for six semesters. Senior High School 4 Bengkulu City 4 is independent school in implementing the 2013 curriculum since 2013. There are 6 English teachers and 30 classes were divided into 10 classes of $10^{\text {th }}$ grade, 10 classes to $11^{\text {th }}$ grade, 10 classes to $12^{\text {th }}$ grade. The researcher will take 3 teachers and 4 classes in $10^{\text {th }}$ grade class to represent the population as sample.

The researcher use observation checklist in this study. A checklist is an instrument in which the required elements of a performance or product are listed and a score is assigned based on whether the element is present or not. They are useful devices for assessing simple performances or achievement in which the individual elements being assessed typically involve dichotomous types of judgments. The instrument of observation is checklist and record. The researcher marked $(\sqrt{ })$ in the column of the checklist if the teacher implemented the Scientific Approach in teaching and learning process.

communicating. Besides the teacher should choose the authentic materials and do authentic assessment to support the implementation of scientific learning approach it

\section{Result of scores on reliability of observer and co-observer}

Based on the result of inter-rater correlation analysis shows that about $82.63 \%$ agreements in category almost perfect; the inter-rater disagreement only on phase observing in steps on teaching scientific learning approach. 
The scores on reliability of the observer and co-observer are presented

in the table 1.below:

Table 1

Summary Calculation Percentage of Agreement between Rater

\begin{tabular}{|c|l|l|l|}
\hline $\begin{array}{l}\text { Teacher implementation of } \\
\text { scientific learning approach }\end{array}$ & $\begin{array}{l}\% \\
\text { Agreement }\end{array}$ & $\begin{array}{l}\text { Level of } \\
\text { Agreement }\end{array}$ & $\%$ of Reliable \\
\hline $\begin{array}{c}\text { Implementation of } \\
\text { stage in Scientific } \\
\text { learning approach }\end{array}$ & & & \\
\hline a. Observing & 69.94 & Moderate & Almost Perfect \\
\hline b. Questioning & 81.51 & Strong & Almost Perfect \\
\hline c. Exploring & 79.43 & Moderate & Almost Perfect \\
\hline d. Associating & 84.90 & Strong & Almost Perfect \\
\hline e. Communicating & 76.56 & Moderate & Almost Perfect \\
\hline $\begin{array}{c}\text { 1. The implementation of } \\
\text { learning material }\end{array}$ & 92.95 & $\begin{array}{l}\text { Almost } \\
\text { Perfect }\end{array}$ & Almost Perfect \\
\hline $\begin{array}{l}\text { The implementation of } \\
\text { authentic assessment }\end{array}$ & 93.05 & $\begin{array}{l}\text { Almost } \\
\text { Perfect }\end{array}$ & Almost Perfect \\
\hline Amount & 578.39 & & \\
\hline Average & 82.63 & & Almost Perfect \\
\hline
\end{tabular}

From the description of the table, it shows that based on the five steps in implementation of Scientific Learning Approach almost all categories are moderate but in phase observing, some aspects do not appear. In the implementation of learning material the percentage of agreement is satisfying with the category almost perfect $(92.95 \%$ agreement) and the implementation of authentic assessment reaches $93.05 \%$ agreement in category almost perfect too.

\section{The Result of the observation}

Here the observation that the researchers do in implementation of Scientific Learning Approach used by the teacher in classroom. In these steps, there are five phases in implementing this approach namely: Observing, Questioning, Exploring, Associating and communicating phase. In each phase consists of some criteria's that are expected to be conducted by the teachers. The observation was done in two meetings. The total participants were three teachers. In this section will be discussed in three parts. The first is the steps of scientific learning approach in: a. Observing Phase b. Questioning Phase c. Exploring Phase. d. Associating Phase e. Communicating Phase. The second is the materials which are developed by the teacher to support the implementation scientific learning approach in class. And the third one is the teachers assess the learning process in implementing scientific learning approach in class.

Table. 2

RESULT FOR IMPLEMENTATION OF SCIENTIFIC LEARNING APPROACH 
Hikma Wipaqi, Azwandi, Arono, The implementation of...

\begin{tabular}{|l|c|c|}
\hline $\begin{array}{c}\text { STEPS IN SCIENTIFIC } \\
\text { APPROACH }\end{array}$ & AVAERAGE & CATAGORIES \\
\hline OBSERVING & 2.80 & Fair \\
\hline QUESTIONING & 3.15 & Good \\
\hline EKSPLORING & 3.18 & Good \\
\hline ASSOCIATING & 3.47 & Very Good \\
\hline COMMUNICATING & 3.06 & Good \\
\hline AVERAGE & $\mathbf{3 . 1 3}$ & Good \\
\hline & & \\
\hline LEARNING MATERIAL & 3.72 & Very Good \\
\hline & & \\
\hline AUTHENTIC & 3.74 & Very Good \\
\hline ASSESSMENT & &
\end{tabular}

\section{Observing Phase}

In observing phase $69.94 \%$ of the teacher's performance implemented this phase were in very good category. Based on the result of data in observing, some criteria in observing phase were implemented by the teacher in classroom well. In observation, the researcher found that some teacher did all criteria in observation phase.

There were two criteria that were rarely implemented by the teacher in the classroom relate to the observing through watching video and observing voice recording. Mulya ( 2015 ) also found in his research that in observing phase, watching video and observing voice recording were not implemented in teaching during class it caused that the teacher ignore and left them based on their thought that all information in observing phase could implicated through the information in picture only. Besides that, other reason was lack of facility that made the teacher reluctant to do that they also thought that the information and material should not always used video in learning. .Daryanto ( 2014 ) said that in practicing of observation in learning, that will be effective whether the students and teacher completed themselves with recorded instrument and other instruments as like : tape recorder, camera, film or video and other things relate to their needs. Otherwise, the use of audio and visual media was very important to support the scientific learning approach in teaching and learning process. Audio visual can help the student to illustrate the real phenomena or real object and audio media voice recording were very effective and efficient for students to learn especially respective skill.

\section{Questioning Phase}

Questioning is the second step in this phase. Almost all of the criteria were implemented by the teachers. Based on the finding, most of the teachers has done all of the criteria in questioning phase belong to good category. In this phase, researcher found that the teachers gave a chance for the students to ask about something relate to the material. The teacher guided the students and give curious question in order to make the students think and stimulate them. Effective teachers can inspire students to improve and develop the realm of attitudes, skills and knowledge. By the time the teacher asked, at the same time he guided or guide their students to learn well. When the teacher answered questions learners, when the same instant he pushed her care was to be good listeners and learners. The function of the inquiry, including: generating curiosity, interest, 
and attention to learners about a theme then encourage and inspire learners to actively learn and develop questions of and for it. Diagnose learners' learning difficulties and expressed definition to find a solution, structuring tasks and provides opportunities for learners and generating learner's skills in speaking, asking questions and giving answers logically, systematically, and use language that are good and true. (Permendikbud No. 81a Th. 2013).

Another finding also found that in questioning phase, the teacher focused on group discussion where only some student eagerly to ask the question about the topic. Pahlevi (2013) got that the teachers were less effective to develop student's curiosity of the students to explore to think and ask the question.

In fact, there was one teacher in first meeting less implement in some criteria in question phase. From the observation, researcher found that the teacher was much less in giving chance to the students to ask. The teacher handles the all information about the material and the students just listen to the information from the teacher. The teacher dominated in this process. The discussion and students question was not seen in this activity. The teacher was much less giving question so there were not interactions between students to share the information and solve the problem.

\section{Exploring Phase}

Third step is exploring phase. The teacher's performance in the exploring phase come to seventy-nine point fourth- three percent or the average three point seventeen from eight criteria. It belongs to good performance from exploring step. Only some aspects are rarely using as like teacher train the students to do simulation and do role play to their material. In this phase, teachers are expected to improve student's curiosity in developing communicating.

In exploring phase, Kartikawati (2015) stated in his research that the teacher only has lack of knowledge about the implementation of scientific process in teaching and learning. Then they also got some difficulties in mastering of each stage. They tent to pocus on pattern. The teacher did not use associating phase because those stage are the same with experimenting stage. The other reason was that the teacher just explained about the text pattern when they taught the material. Then some stages left it was caused by the limitation of time.

From the data of observation, the teacher's performances are good in observing the particular event and he/she trained their skill trough structured activity. They only focused on structured activity. The students do the exercises or task intensively. It seem that the teacher tend to teach structured as well as possible. Besides only a few teachers used media. The major teacher just explained based on their experienced and focused the information that they got in textbook without add the information from other sources. It means that the teachers only focused on task and assignment in textbook. Actually the teacher should develop the student's competency as a contentious attitude, honest, polite, respect other people's opinion, abilities communicating, implementing the ability to gather information trough variety of ways to learn, develop the habit of learning and long life learning ( Kementrian Pendidikan dan Kebudayaan, 2017)

\section{Associating Phase}

Fourth step is associating phase. They are five criteria here. The averages of teacher's performance are three point fourth-seven belong to very good category. In observing, researcher found in this activity teacher divided the 
Hikma Wipaqi, Azwandi, Arono, The implementation of...

students become small group discussion. Each group consists of 4-5 members. Teacher guided an instructed them some tasks and assignments. It seems the teacher gave the chance to the students to share the information, found the arguments and made conclusion in order to solve the problem. The students discussed well to solve the problem to finish the task. They were looking for such information to find and analyzing the generate structure of the text, language features, and content of the text. The teacher implemented this associating phase in the classroom appropriated with the Degree of the Ministry of Education and Culture No. 81.A 2013. Associating is the process of thinking logically and systematically above facts empires words that can be observed to obtain conclusion in the form of knowledge.

\section{Communicating Phase}

The last step is communicating phase. It consists of eight criteria. The data shows that seventy-six point fiftysix percent present the teacher's performance in this phase was in good category. The teacher did this step trough making group discussion. It saw that this stage conducted well where all of criteria were implemented only at the first meeting some aspect was not appearing. It was not present the pictures and the editing of friend's report.

Mechanical correcting the students' activities peers in reading his writings in order to make a response in the form correction in his position as a reader students seek and find fault. In addition correction that the students do in peers will be more easily understood; Suryani in Stevic and Walz, 1982, revealed that the administration of correction by peers is an error correction method which is more informative because it is given by people who have comparable abilities.

\section{Learning Material}

For the second research question is about how materials are developed by the teacher to support the implementation scientific learning approach in class. Almost of the teacher has implemented the learning material well. It showed from the result of observation in class, which in this phase included in category almost perfect.

In developing learning materials the teacher developed the instructional which material refers to learning materials in the syllabus and basic competence in all three core competencies (knowledge). It is suitable with Permendikbud number 59 of 2014 mentioned that English competency in question is the competence dimension of attitude, understanding, and skills. The procedure, a series of incremental steps and systematic in applying the principle. Procedural steps are part of competence in skill aspect. In English class, the teacher did the step compose the text as an integral part in every matter of learning materials.

However in conducting instructional, similarly with Kartikawati (2015) found that most of teacher used a printed material even though that material was relevant to the syllabus and curriculum but it was inadequate. It should be supported by the unprinted materials

The Assessment

The third research question is how the teachers assess the learning process and product in implementing scientific learning approach in class. From the observation in this phase, it seems that almost of the teachers implemented the authentic assessment in teaching and learning process. An Authentic assessment has strong relevancy to the scientific learning approach relate to the demands of 2013 curriculum. It is caused by this assessment hoped improve the result of 
students mastery of learning in observation, questioning, exploring, associating, and communicating.

In class, the teachers assess the students used authentic assessment models. They assess the students' trough observation, giving the tasks and student's performance in practicing their skill. In this process teacher asked students to demonstrate knowledge (knowledge), Attitude (affective), Skills (skills) and ability (ability) In a real situation /real life situations. The teachers implemented authentic assessment as a comprehensive assessment which assess the start of the input (input), process, and outcomes (outputs) of learning. (Permendikbud No. 66/2013).

In this process of scientific learning approach, teacher did the procedures of implementing the assessment. The assessment instrument was provided to give an opportunity for learners to apply knowledge, skills, and attitudes that already had in the form of tasks such as reading and writing in the real world and in school, presentations, observe, survey, project, paper, create a multi-media, an essay or class discussion. The aim was to assess different types of language skills in a context that is almost close to a real situation. Teacher divided the students in groups which cosmist of five or six members. Each group chose a topic relate to the material and make group discussion. The teacher would assess trough discussion activity, group performance and the report that the student made. Material and assessment tasks should be made as natural as possible. Besides authentic assessment appreciated the ability to think and learning process and the outcomes of the learning process. Based on the predetermined task, Teacher need to develop scoring rubric and observation check list to determine what aspects need to be done by students and whether students have done a good job.

\section{CONCLUSION}

This research aimed to find out the implementation of Scientific Learning Approach at X Grade English Classes of Senior High School 4 Kota Bengkulu. Based on the result of discussion of this research, several conclusions can be explained to answer of this research:

1.The majority of the teachers implemented the Scientific learning Approach. They are observing, questioning, exploring, associating and communicating, but some teacher's performance were still lack of implementing some phase and criteria especially in observing phase through watching video and observing voice recording. Actually in Scientific Learning Approach, students are hoped more active and creative to add their horizon of thinking in order to get the knowledge

2. Almost most of teachers implemented the learning material well. The teacher improves the leaning material based on the syllabus and basic competence relate to the curriculum. Basically the principle of choosing learning material was fulfilled consisting of relevance, principle, consistence and term of reference. The authentic assessment has been done by the teachers on an -going process. In this case that the authentic assessment require learners not only to answer the test correctly, but also to apply their knowledge, skill and attitude to solve their problem of everyday life or real life context.

\section{REFERENCES}

Abedi, J. (2010). Performance assessments for English Language learners. Stanford, CA: Stanford University. Standford Center for Opportunity Policy in Education. 
Hikma Wipaqi, Azwandi, Arono, The implementation of...

Achmad Yudi Wahyudi. (2015). A Closer look at the Implementation of the Curriculum 2013 in Indonesia: Should the Scientific Approach Be Used in EFL Classroom. RJES Vol. 2. No. 2, July

Akhmad Sudrajat. (2008).

Pengembangan indikator pncapaian kompetensi dasar.http://akhmadsudrajat.wor dpress.com/2008/08/15/pengem bangan-indikator-dalam-ktsp.

Arikunto, S. (1998). Prosedur penelitian suatu pendekatan praktek. PT. Rineka Cipta. Jakarta.

Daryanto. (2014). Pendekatan pembelajaran saintifik kurikulum 2013.Gava media

Don K. Mak, Angela T. Mak, Anthony B Mak. (2009) Solving everyday problems with the scientific method thinking like a scientist world scientific. Publishing Co. Pte. Ltd

Direktorat Pembinaan SMA. ( 2013). Model pengembangan penilaian hasil pelajar peserta didik SMA. Pendidikan dan Kebudayaan Direktorat Jenndral Pendidikan Menegah Direktorat Pembinaan SMA 2013.

Drs. M. Taher. (2014). Implementasi model pembelajaran yang relevan dengan pendekatan ilmiah pada kurikulum 2013. http//sumut.kemeneg.go.id

Education Scotland. (2014). The curriculum for excellence implementation plan for 2015 2016 sets out the key strategic priorities that national partner. (Scotttish Government, Education ).http://educationscotlland.gov.u $\mathrm{k} /$ resources/c/generiesourcetcm4863260.

Fadillah. (2014). Implementasi kurikulum 2013 dalam pembelajaran SD/MI, SMP/MTs, \& SMA/MA. Ar Ruzz, Yokyakarta

Grace Keyes, (2010). Teaching the scientific method in the social sciences The Journal of Effective Teaching, Vol. 10, No. 2, 2010, 18-28

Imas Kurinasih dan Berlin Sani. (2014). Implementasi Kurikulum 2013 Konsep dan Penerapannya. Surabaya: Kata Pena

Jack R. Fraenkel Norman E. Wallen Helen H. Hyun. (1990) How_to_design_and_eraluate_r esearch_in_education.http:///ww w.academia.edu/3642866

Jean-Claude Beacco, Michael Byram, Marisa Cavalli, Daniel Coste, Mirjam Egli Cuenat, Francis Goullier and Johanna Panthier . (2010). Guide for the development and implementation of curricula for plurilingual and intercultural education. Directorate of Education and Languages, DGIV Council of Europe, Strasbourg

Kartikawati, Yeni (2015). The implementationof scientific learning approach in teaching English. Thesis, Univ Muhammadiyah Surakarta.

Kementrian pendidikan dan Kebudayaan, (2013). Materi pelatihan guru implementasi kurikulum 2013. Jakarta: Depdikbud.

Kementrian pendidikan dan Kebudayaan,(2013). Modul pelatihan guru implementasi 
kurikulum 2013. Jakarta: Badan Sumber Daya Manusia Pendidikan dan Kebudayaan.

Kementrian Pendidikan dan Kebudayaan, (2013). Peraturan mentri pendidikan dan kebudayaan No 65 tentang standar proses pendidikan dasar dan menegah. Jakarta: Depdikbud.

Kementrian Pendidikan dan Kebudayaan, (2013). Peraturan mentri pendidikan dan kebudayaan No 81a Tahun 2013 tentang implementasi kurikulum 2013. Jakarta: Depdikbud.

Mardiyah Khoiroh. (2015). Penerapan pendekatan scientific pada pembelajaran Bahasa Indonesia kurikulum 2013 siswa kelas X SMK Negeri 1 Kota Bengkulu. FKIP.Unib

Marilyn M. Lombardi . 2008. Making the Grade: The role of assessment in authentic learning . Educate Learning Initiative.

McCollum, Kimberly. (2009). "A Scientific approach to teaching

http://kamccollum.wordpress.co $\underline{m / 2009 / 08 / 01 / a-s c i e n t i f i c-}$ approach-to-teaching/

McHugh ML (2012). Interrater reliability: the kappa statistic. Bio Med (Zagreb)

Muller, Jonahan. (2008). "Authentic assessment toolbox". http://jonathan.mueller.faculty.noctrl.edu/toolb ox/index.htm

Mulya, Debby. (2015). The implementation of scientific learning approach in the 2013 curriculum English classess at junior high school Kota Bengkulu.Thesis, FKIP Universitas Bengkulu.

Mulyasa. (2014). "Pengembangan dan implementasi kurikulum 2013". Bandung. Remaja Rosdakarya

Nana Syaodih S. ( 2009). “ Pengembangan kurikulum teori dan praktek" PT Remaja Rosda Karya. Bandung

Nurul, H (2013). Pengertian dan langkah-langkah saintifik. http://www.nurulhidayah.net/87 9-html.

O'Malley, J. M., \& Pierce, L. V. (1996). Authentic assessment for English language learners: Practical approaches for teachers. Reading, Mass: Addison-Wesley

Reza Pahlevi M (2014) .The implementation of scientific approach in teaching writing based on the 2013 in junior high school. Thesis, FKIP.Universitas Negeri Surabaya

Tega Jesya. (2016). What are the steps of Scientific methods http://www.universetoday.com/7 4036/what-are-the-steps-of-thescientific-method/

Pembelajaran Berbasis Kompetensi Mata Pelajaran Bahasa Inggris Melalui pendekatan Scientifik, (2013). Kementrian pendidikan dan Kebudayaan Direktorat Jendral Pendidikan menegah SMA

Peraturan Menteri Pendidikan dan Kebudayaan. (2013). Peraturan menteri pendidikan dan Kebudayaan nomor 69 tahun 2013 tentang Kerangka Dasar 
Hikma Wipaqi, Azwandi, Arono, The implementation of...

dan Struktur Kurikulum Sekolah Menengah Atas/Madrasah

Aliyah. Jakarta: Kementerian

Pendidikan dan Kebudayaan.

Peter Koss. (2011). A Summary of scientific method. Springer Dordrecht Heidelberg London New York

Sujana. (1989 ). Metoda Statistika. Edisi ke V. Bandung

William Badress.( 2000). Methods of assessment. http: //www.eduplace.com/wetpience/ profdev/articles/badders.html..

Xiaowei Tang, Janet E. Coffey ( 2009 ). The scientific method and scientific inquiry: Tensions in teaching and learning department of curriculum \& instruction, University of Maryland, College Park, MD 20742, USA 